\title{
Versions and Versioning: A Critical Archive of D. H. Lawrence
}

Paul Eggert

peggert@luc.edu

Follow this and additional works at: https://ecommons.luc.edu/english_facpubs

Part of the English Language and Literature Commons

\section{Author Manuscript}

This is a pre-publication author manuscript of the final, published article.

\section{Recommended Citation}

Eggert, Paul. 'Versions and Versioning: A Critical Archive of D. H. Lawrence'. ARCHIV, 254.1 (2017), 82-95.

This Article is brought to you for free and open access by the Faculty Publications and Other Works by Department at Loyola eCommons. It has been accepted for inclusion in English: Faculty Publications and Other Works by an authorized administrator of Loyola eCommons. For more information, please contact ecommons@luc.edu. cc) (i) $\Theta$

This work is licensed under a Creative Commons Attribution-Noncommercial-No Derivative Works 3.0 License. (c) ERICH SCHMIDT VERLAG 2017 


\title{
VERSIONS AND VERSIONING
}

\author{
A CRITICAL ARCHIVE OF D. H. LAWRENCE * \\ Paul Eggert \\ Loyola University Chicago
}

To begin to understand the archive of extant D. H. Lawrence materials and of editorial dealings with them - the main subject of this essay - we need to appreciate the bookhistorical context that gave rise to those materials in the first place.

The anglophone book-history movement, when it got properly going in the early 1990s, made editors like me see that, as a historian of the texts of works, texts that were being bought and sold, you had to follow the money trail to understand what was happening. You had to grasp that intellectual property was fundamentally something that could be bought and sold. It was not moral copyright, a concept that came more naturally to the French. The British legal case of Millar vs Taylor (1769) had ensured that. ${ }^{1}$ Successive copyright regimes from 1842 in Britain codified the understanding, with the effect that books became progressively cheaper and cheaper as publishers went in search of profit. They expanded their readerships via smaller-format books, at the very moment when new printing technologies came on-stream and then, from the 1870s, when education became nearly universal. ${ }^{2}$ As a result, in 1885 , D. H. Lawrence was born into a marvellous new world of widespread literacy and the ready availability of print. Fast forms of transportation and communication, both within Britain and worldwide, were annihilating distance and permitting efficient commerce in printed goods.

A new modernity had arrived. New audiences were formed. Lawrence and Jessie Chambers were of course one of them in the first decade of the twentieth century. In her memoir D. H. Lawrence: A Personal Record (1935), she tells the story of their discovery of the recently established English Review, a godsend, a lifeline, to these two seriousminded young people in the Midlands who were reading their way through their literary inheritance, one that had been unavailable to their grandparents and their forebears at the same age.

By the time the young Lawrence turned six, the Chace Act became law in the USA, changing forever the nature of US/UK copyright in ways that would benefit literary

\footnotetext{
* This essay is a revised version of a paper ('Studying Works, Studying Versions: The Distributed Archive of D. H. Lawrence') given at a session called 'Lawrence, Editions and Critical Renewal', at the January 2016 MLA conference in Austin, Texas. The later-written Coda is a result of a question at this session. The essay retains some of the first-person informality of the original occasion.

1 See further Paul Eggert, Securing the Past: Conservation in Art, Architecture and Literature (Cambridge: Cambridge University Press, 2009), chap. 4.

2 See further William St Clair, The Reading Nation in the Romantic Period (Cambridge: Cambridge University Press, 2004), pp. 1-18, 103-21.
} 
careers. For Lawrence this would be especially potent in the 1920s when his publishers Secker and Seltzer represented him on either side of the Atlantic.

The 1890s, as Lawrence was growing up, was the great age of the newspaper and the profitable publishing house with its inhouse literary magazine, offering dual publication outlets, in magazine and book formats, and also simultaneous publication on both sides of the Atlantic. The booktrade was rapidly making a more professional kind of authorship a career option for aspiring novelists. There was money to be made if you were good enough to find or create an audience. Authors' agents were just establishing themselves and were soon able to intervene profitably on authors' behalves. Onevolume cheap colonial editions, which would soon help bring about the demise of the old three-volume novel form, itself a millstone around the neck of the innovative end of the booktrade, were just getting properly underway in the year Lawrence was born. He benefitted from the format. When Lawrence visited Perth, Western Australia, in 1922 he was surprised to find a copy of The Rainbow in the Book Lovers Institute, banned in England in 1915 but already shipped to Perth, prior to the banning, almost certainly as a colonial edition. It was no coincidence.

Lawrence's career as a professional writer would be shaped, though not always contained, by all of these developments. They also account for much of the surviving archive of Lawrence materials.

What deserves to be called Lawrence's distributed archive was gradually formed in the post-World War II period as his reputation rose. It was competed for by many university and public libraries' special collections and by private collectors around the world, but especially in Britain and the USA and most successfully by the oil-funded and farsighted Humanities Research Center (now, the Harry Ransom Center) in Austin, Texas (hereafter, HRC). Initially first editions and association copies were acquired, and handwritten manuscripts. Later, once they began to be understood as possessing evidentiary value, the typescripts and proof sets of so many of his works were accessioned. And of course his correspondence, including many hundreds of letters to his agents and publishers. The librarians and curators were having, somewhat in the dark, to predict what kinds of documents might be relevant to scholars' enquiries in the future. Fortunately, they erred on the side of a generous inclusivity.

In due course, as scholarship matured, the Lawrence archive was recognised to be even bigger than the author-centric collection I have just described, potentially embracing the archives of all the publishers and agents with whom Lawrence had dealt. These too, if even further distributed, some libraries were interested in saving.

Looking back, we can ask the question quite generally: with what preconceptions did Lawrence editors and other scholars approach the distributed archive from the late 1970s when the Cambridge Edition of the Works of D. H. Lawrence began? ${ }^{3}$ What

3 Discussions about the publication of the Works series and Letters series began in 1968; the Press Syndicate approved them in the early 1970s. Prospectuses were drawn up and published for both series: the Letters in 1973 and the Works in 1979. Publication of the eight Letters volumes spanned 1979-2001; 
shaping did they give it? How - with what categories? with what questions? - did they elicit the knowledge that at first they only half-understood that they were seeking?

A charmingly confessional essay about archive work, which appeared in the May 2015 issue of $P M L A,{ }^{4}$ has caused me to describe the situation in this quizzical way. The article is by Suzanne Bost. It concerns the so-far largely unconsulted but voluminous papers of the US Hispanic writer Gloria Evangelina Anzaldúa, also preserved at the HRC in Austin. Like many a scholar before her, Bost finds the messiness of an author's papers - their scattered contents, the personal presence, the unexpected revelations and biographical tangents - a challenge to established literary-critical shapings of her author.

She finds unknown versions of published stories and asks the question of them: 'Does it thereby become a different story? Is the published version still the authoritative one?'. ${ }^{5}$ She concludes: 'After sifting through folders of multiple drafts of similar, overlapping pieces of Anzaldúa's writings, I felt that establishing clear boundaries around a single work would perhaps be undesirable, even if it was possible'. 6

Obviously there are practical editorial questions unaddressed here, but Bost does not pursue them as she is on an opposite tack in her essay. Her instinct is to celebrate the two-way interactions between the researcher and the archival materials, the changing preconceptions of the researcher as he or she tries to make sense of them, and of what, in summary, she calls the dust: 'Scholar, paper, and information slough bits of themselves onto one another'. She wants to stress the 'material, transcorporeal exchanges'. 'I'm drawn to dust as an organizing principle', she writes. ${ }^{7}$ This conclusion is one that, after Derrida, ambitiously seeks to remove the subject-object polarity conventionally thought to be intrinsic to archival investigation.

In his famous long essay of 1995, 'Archive Fever', Derrida makes the telling observation that archives are not just neutral collections of documents awaiting interpretation. Instead, the very acts of selection and collection that formed the archive speak of kinds

the Works, 1980-2013, with the final volume of the three-volume Poems yet to be published. It will be the fortieth volume.

The Works Edition, according to its Prospectus, 'aimed to be both scholarly and accessible - "designed for the library of the ordinary cultivated reader as well as the university teacher's working library or school library" ': Linda Bree, 'The Cambridge Edition of the Works of D. H. Lawrence', unpublished paper given at the Thirteenth International D. H. Lawrence Conference, Gargnano, Italy, June 2014. I thank Dr Bree, who is Editorial Director, Arts and Literature, at Cambridge University Press, for allowing me to quote from her paper. In total, and excluding the Penguin editions taken from the Cambridge reading texts, she reports that over 95,000 individual volumes of the Letters and Works have been sold around the world.

4 Suzanne Bost, 'Messy Archives and Materials That Matter: Making Knowledge with the Gloria Evangelina Anzualdúa's Papers', PMLA, 103.3 (2015), 615-30.

5 Bost, 'Messy Archives', p. 617 col. 2.

6 lbid., p. 618 col. 2.

7 lbid., p. 625 col. 2. 
of valuing and exercises of power that guide, even predetermine, the kinds of interpretation that will be possible. Although an author-centred archive would seem naturally to respond to author-centred questioning and to the categories that we have traditionally brought to them, that naturalness is the very problem Derrida was trying to expose. 8 Does this argument, I ask myself, apply to what the Cambridge editors of Lawrence made of what they found? And does it matter?

To begin to answer these questions I return to Bost's teasingly paradoxical principle of dust. While it is literally true that archival researchers get their hands dirty and do in turn affect the materials they handle in microscopic ways, 'dust' strikes me as, on its own, too basic or inchoate a level from which to produce usable knowledge. There is, clearly, some conceptual heavy lifting yet to be done if it is to be retained. Even so, there remains something admirably principled about Bost's desire to leave the archive in suspension, in place long enough so that it may set up a dialogue with its researchers before traditional methodological categories are brought into play.

I have summarised Suzanne Bost's argument because it helps define, by the starkness of its contrast, the position from which the Lawrence editors, bibliographers and biographers started in the late 1970s. But the contrast is not so stark with the position at which they arrived - as I will now try to show.

'All truths are contextual', Bost wisely observes: ${ }^{9}$ and so it was in the early days of the Lawrence Edition, as we can see, looking back. When the book-history movement in the anglophone countries got decisively underway in the early 1990s Lawrence editors were ready for it because they - because we - had already been puzzling our way through the archive, dealing with questions of magazine and simultaneous book production, author-agent relations and copyright. Nearly all of us had been trained only as literary critics, so this was new territory at first.

The man at Cambridge University Press who had initiated the Lawrence Works series in the late 1970s, Michael Black, had been trained by F. R. Leavis in the 1940s and consequently believed in the spiritually healing effect of important literature, Lawrence's writings foremost among them. However, unlike Leavis and professional publisher as he was, Black found he could not casually dismiss the role of literary scholarship - as opposed to literary criticism, of which Leavis was his great exemplar. Black gradually came to see, as he states in his memoir Learning to be a Publisher, that Lawrence's

\footnotetext{
8 Jacques Derrida, 'Archive Fever: A Freudian Impression', Diacritics, 25 (1995), 9-63. Derrida's tactic, continuing a line of argument initiated by Michel Foucault, was to deprivilege the material basis of the archive by diverting its explanatory power elsewhere ('The achivization produces as much as it records the event', p. 17; 'There is no political power without control of the archive, if not of memory', pp. 10-11 n. 1): see further Paul Eggert, 'Brought to Book: Bibliography, Book History and the Study of Literature', The Library, 7th series, 13.1 (2012), 3-32.

9 Bost, 'Messy Archives', p. 624 col. 1.
} 
writings were, at any one time, in co-evolution with one another. ${ }^{10}$ Therefore chronology was crucial. Keith Sagar's brief chronologies at the start of each chapter in his book The Art of D. H. Lawrence of 1966 had, for Michael Black, signalled a shift in interest. ${ }^{11}$ Chronologies revealed to Black that studying versions of works was crucial. Therefore we had to have access to all the correspondence: indeed those eight Cambridge Letters volumes rapidly became, for the Cambridge Works editors, the principal distillation of the archive, the first port of call when trying to understand the gyrations that the work being edited had gone through. But ultimately editors also needed access to the broader archive.

Mark Kinkead-Weekes solidified and extended what Black first found in Keith Sagar. But even in the late 1970s, as a PhD student at the University of Kent at Canterbury where Kinkead-Weekes taught, I realised that he too could not quite shake free of the Leavisite earnestly meditative mode. This was despite his ground-breaking essay of 1968, 'The Marble and the Statue', tracking the continuity of ideas from Sons and Lovers through the Study of Thomas Hardy to The Rainbow. ${ }^{12}$ Prior to that, the two novels had normally been treated as two mountain-peaks of achievement, but the subterranean filaments of thinking and imagining that joined them were little appreciated.

Kinkead-Weekes continued to research this part of Lawrence's oeuvre by delving into the D. H. Lawrence collection at the HRC in Austin. Its archive helped him to unearth more of those connecting filaments so as to give their gradual evolution a more nuanced account. Returning to Kent he gave a paper to the postgraduates, of whom I was one, on what he had found. Such literary archaeology was felt at the time to be slightly infra dig or beside the point - to be 'mere' scholarship. Even in the late 1970s, Kinkead-Weekes still felt he had to counter this climate of expectation. But to me, working on related material for my $\mathrm{PhD}$ thesis, his discoveries seemed almost miraculous, paradigm-breaking. The climate of expectation that his own native earnestness about literature bridged told us, I felt, more about what the 1950s and 1960s decades needed Lawrence to stand for than about Lawrence himself. KinkeadWeekes had come to the archive with authorial preconceptions, true - and to that extent the Derridean case holds - but new, unexpected knowledge was palpably being produced. It was in the very air as he spoke.

Michael Black and he had seen that Leavis's prejudice against textual scholarship - as mere 'fiddling about with the details' - was wrong. ${ }^{13}$ Kinkead-Weekes's great edition of

\footnotetext{
10 Michael Black, Learning To Be a Publisher: Cambridge University Press 1951-1987 Personal Reminiscences (Cambridge: privately published, 2011).

11 Keith Sagar, The Art of D. H. Lawrence (Cambridge: Cambridge University Press, 1966).

12 Mark Kinkead-Weekes, 'The Marble and the Statue: The Exploratory Imagination of D. H. Lawrence', in Imagined Worlds: Essays in Honour of John Butt, ed. Maynard Mack and lan Gregor (London: Methuen, 1968), pp. 371-418.
}

13 Black, Learning to be a Publisher, p. 241. 
The Rainbow and his volume II of the Cambridge Biography of Lawrence followed through on the insight. ${ }^{14}$ Mark fussed with every detail, any one of which might, if pondered long and sensitively enough, be found to be indexical of the elusive truth he was seeking about the essential continuum of Lawrence's writing and thinking at any one time, about its contours and nature.

I use Kinkead-Weekes's case only as an example of what the editors faced. The demands that the Edition laid on them both powered and constrained their dealings with the distributed archive. For a start, there was the expectation that one's engagement with the archive was outcome-directed. Editions were to be the outcome. The suspension of the interpretative gaze that Suzanne Bost postulates could not even be envisaged in those days. Pragmatism was the driver.

Rhetorically in one's editorial work, appeal to the unpublished archival document as the source of one's evidence seemed to found the enquiry upon a rock of objectivity outside of and prior to the interpretation. Yet this appeal is the very thing that Derrida would later expose as an illusion since the document's attributed meaning, he argued, was always already preconditioned by the parameters of interpretation that were brought to bear on it. Now it is true that, in some absolute sense, Derrida is right. There is no ground zero for archival research. Despite the fact that the document's physical existence is what we cite and that this existence is conceptually separable from its meaning or meanings the document and its textual meanings are nevertheless locked forever in an embrace that the reader revives, brings into the light once again, in the moment when he or she engages with the archival-semiotic scene. Or, to put it less grandly, we bring presuppositions with us to the archive and the danger is that they may crowd out other possible ones. In a sense, this is Bost's point.

Yet even armed with such presuppositions the ascertaining of the meanings of an archival document is rarely a straightforward affair. There is always a process of engagement. Meaning needs to be elicited. It is a two-way thing, just as Bost says. Surprises await the scholar at every turn since the archive is always in excess of the chosen path of enquiry and even of the original motives of collection. Comparisons and cross-checks with data - even if only the date - of other documents need to be carefully done until that data turns into information, and information into evidence in the service of an argument. If presuppositions are inevitable but also disputable and extendable, then the archival engagement needs surely to be judged not by its vacating of an impossible, unreachable ground zero but by the fruitfulness or otherwise of the enquiry.

Another way of putting this is to observe that the Cambridge editors stepped purposefully in one direction, with the results - nearly forty volumes - that we see upon our shelves. Yet the archive remains in existence, awaiting other kinds of research methodologies once they can be conceived of and put into operation.

14 D. H. Lawrence, The Rainbow, ed. Mark Kinkead-Weekes (Cambridge: Cambridge University Press, 1989). Mark Kinkead-Weekes, D. H. Lawrence: Triumph to Exile, 1912-1922 (Cambridge: Cambridge University Press, 1996). 
So how, in practice, did the Cambridge editors approach the distributed archive of D. H. Lawrence? Speaking as one of them I can testify that our dealings with the archive were gently undoctrinaire, amateurishly untheorised. It was a stumbling love affair. The teasing incompleteness of the archival evidence was seductive. The truth, say, about the transition of this version into that might be imperfectly in view; but a nearer approach seemed to beckon. The archive was giving us, as we studied the documents, new and better glimpses of the author in action, his living as writing, his writing as living. And yet we were editing works each one of which needed to be separately contained within the hardback boards of a single volume that would be saleable within the scholarly marketplace.

Where we editors started is, however, not where we finished. We started establishing the final-intentions texts of works, and ended up realising we were editing versions late ones. ${ }^{15}$ Versionality proved to be inherent in Lawrence's writings, with any one version of a work likely to be connected in revealing ways with versions of other works written at roughly the same time. There are, for instance, two post-Mollie Skinner versions of The Boy in the Bush. ${ }^{16}$ Publication of Lawrence's first version of 1923, despite its ostensibly Australian subject matter, would, had it gone ahead, have helped document the development of his thinking about America through the many essays, travel writings and reviews he wrote in the few years after 1922, together with the two versions of The Plumed Serpent. As it is, the early version of The Boy in the Bush is only retrievable through the textual apparatus of the second, published in 1924.

Again, Reflections on the Death of a Porcupine (1987) provides a reading text of the 1925 version of Lawrence's long wartime essay 'The Crown' because it was the final one. But, for anyone working on the Lawrence of 1915, the version of that year, unchanged by the later revisions and partial rewriting, is the crucial source with which to engage. One must use the apparatus in the published volume to retrieve it. ${ }^{17}$ Similarly, the recent two volumes of The Poems provide the texts, and in apparatus record the production variants, of the poems Lawrence revised for Collected Poems in 1928. ${ }^{18}$

15 It is true that the initial Edition prospectus of the late 1970s had envisaged supplementary volumes to cover the already known three versions of Lady Chatterley's Lover and, as I recall, the early version of Sons and Lovers. But the need for a First Women in Love and (I think) Quetzalcoatl, the first version of The Plumed Serpent, only emerged during the editing of the originally published later versions.

16 See Introduction to the Cambridge edition of The Boy in the Bush, ed. Paul Eggert (Cambridge: Cambridge University Press, 1990). The novel is Lawrence's rewriting in 1923 of M. L. Skinner's novel 'The House of Ellis', sent to Lawrence in typescript but subsequently lost.

17 Reflections on the Death of a Porcupine, ed. Michael Herbert (Cambridge: Cambridge University Press, 1987).

18 The Poems, ed. Christopher Pollnitz, 2 vols (Cambridge: Cambridge University Press, 2013). The Collected Poems of D.H. Lawrence (London: Secker, 1928). 
Eggert . 'Studying works, studying versions' . p. 8

This is despite the likelihood that many scholars may well be more interested in the versions of the original collections and what lay behind them.

The organisation of the Cambridge Works Edition was oriented from the start around the names of the volumes published in Lawrence's lifetime. It was the obvious recourse in the 1970s. The and Other formula attached to these names in the titling of some of the Cambridge volumes was intended to gather up most of the estrays. For The Prussian Officer and Other Stories (1983) this organisational principle, together with a prejudice in favour of choosing as copy-text the last complete one Lawrence worked on, meant that the earlier published and unpublished versions of the stories went mainly unrecorded in the apparatus. Their texts were pre-copy-text and there was therefore no editorial obligation to record them. ${ }^{19}$

A token of how much was learnt during the four decades of the Edition was the appearance of The Vicar's Garden and Other Stories in 2009.20 It finally made good what had been learned the hard way, through editorial engagement with the archive. Early versions of short stories in The Prussian Officer (1983) and of England, My England and Other Stories (1990) were gathered, edited and recorded.21 Similarly, the anticipated third volume of Poems will make good the deficiency mentioned above. My own volume, Twilight in Italy and Other Essays of 1994 was something of a breakthrough in that it presented all versions in chronological order. The achievement, thus stated, sounds minor now; but the original organisational logic of the Cambridge Works series militated against the outcome. The other breakthrough in the series was a tendency that gradually prevailed to choose early-state copy-texts, manuscript if possible, so that the apparatus would then be obliged to record the full history of the work.

So, as I see it, the essential versionality of Lawrence's writings was one discovery that study of the distributed archive brought to the surface. The other main discovery was the deep relevance of book history to scholarly editing. It amounted to more than the general condition described at the beginning of this essay. I can put it this way. No matter Lawrence's inspiring ideals, there could be no purely spontaneous exercise of creativity since he was always writing for readers. Every act of writing presupposed an act of reading - initially his - that would soon be mediated by a publishing industry. Lawrence needed to earn a living by his pen. His textual inscriptions had to be transmitted through documents within publishing contexts that had determining effects, of different intensities at the various stages of his career.

19 The Prussian Officer and Other Stories, ed. John Worthen (Cambridge: Cambridge University Press: 1983).

20 The Vicar's Garden and Other Stories, ed. N. H. Reeve (Cambridge: Cambridge University Press: 2009).

21 England, My England and Other Stories, ed. Bruce Steele (Cambridge: Cambridge University Press, 1990). 
To the idealistic Lawrentian this is not always a welcome message, and that is why, I suspect, its implications remain under-explored.22 When I first read his book of $1979 D$. $H$. Lawrence and the Idea of the Novel, I remember feeling affronted by John Worthen's insistence on rubbing the reader's nose in Lawrence's business dealings and his changing sense of his readership. ${ }^{23}$ How was this relevant to my Lawrence?, I asked myself indignantly at the time, standing on my postgraduate pride. But, by the time of Worthen's 1989 short biography D. H. Lawrence: A Literary Life, I was convinced it was. ${ }^{24}$ I had been editing for some years by then. Empirical work soon makes you learn to follow the evidence. The new book history movement was only just on the horizon; the formation of its professional association SHARP was still a few years away. Worthen had discovered the relevance of book history to Lawrence himself without yet knowing what to call it. He did it by digging in the archive and reflecting on its relevance to the author he was studying.

It turned out that one's dealings with the archive were not, and cannot be fairly described as, a predetermined affair or a passive channelling of a pre-existing discourse. The job was, in practice, an engagement. It was a learning process out of which much was achieved. Inoculation against Derrida's archive fever turned out to be unnecessary.

\section{Coda: A Versional Lawrence Archive and Edition?}

For many years now Cambridge University Press has been making the individual Lawrence Works volumes available in paperback print-on-demand format, once their initial hardback print run is exhausted. There are also I understand, plans to market the complete works as an inexpensive paperback set (minus, I am told, the Poems volumes whose hardbacks of 2013 are still selling steadily). Furthermore the Press plans an electronic publication of the Works as part of its new Cambridge Scholarly Editions OnLine initiative, to be modelled on the existing Oxford University Press equivalent.

Oxford's published scholarly editions are gradually being input to computer and marked up with XML codes for significant features (such as act-scene-line identifiers, genre, author, title, date, annotation, variant reading); this facilitates subsequent searching and linking. Thus character-string and more complex searching across the volume (and across collections of volumes) becomes possible, as well as the capacity to put a page of reading text alongside, and scrolling synchronously with, the relevant editorial annotation and the record of variant readings. A scan of the relevant print page is also accessible and may be saved as a pdf and printed off. These advances will be useful

\footnotetext{
22 I have made two attempts: 'D. H. Lawrence, Henry Lawson and Single-author Criticism', D. H. Lawrence Review, 36.2 (2011), 2-26; and 'Lawrence, Twilight in Italy and the Limits of the Foreign: A Print Culture Approach', in Lake Garda: Gateway to D. H. Lawrence's Voyage to the Sun, ed. Nick Ceramella (Cambridge: Cambridge Scholars Publishing, 2013), pp. 25-54.

23 John Worthen, D. H. Lawrence and the Idea of the Novel (London: Macmillan, 1979).

24 John Worthen, D. H. Lawrence: A Literary Life (London: Macmillan, 1989).
} 
ones for scholars, and may encourage more use of end-of-volume content (annotation, commentary, textual apparatus) than is typically the case with the printed form. A lot depends, however, on the accuracy of the inputting, both of the text and its encoding.

There is a commercial consideration here. In Cambridge's case the increased utility will allow the sale of subscriptions to institutional libraries. These represent a way for the Press (and presumably for the Lawrence Estate) to extract more value from the intellectual property that it controls. I am in favour of university presses securing such added returns on their investment. The publication of high-level scholarship is anything but cheap, especially in an era of falling print runs for scholarly works. And, in Cambridge's case, the Press has shown remarkable commitment in sticking with the Lawrence Letters and Works series for over 40 years now.

However, the likely success of the Oxford model of online scholarly editions raises a worrying question. How long can it be before the large university presses make the obvious move, for new scholarly editions, of skipping the printed form altogether, or printing the readings texts only, leaving the editorial matter for online presentation only?

If such a prospect is on the agenda of university presses the model described above would be a poor one to follow. This is because it is a derivative model. Although it permits the aggregation of content (many editions) and searching across them - and to that extent breaks down the enclosure of a hardback's contents - it assumes the existence of the printed editions in the first place and is modelled around the logic of their internal organisation and establishment of content.

For this reason the emergence of a versional Lawrence, for which I argued above, would also be ill served by this model. The restriction of access to the print editor's perspective or the series perspective cannot finally be overcome by XML encoding. Another more fundamental move, a rebuilding from the ground up, is going to be required. How might it work?

For a start it would have to put the reader-user in immediate contact not with the printed edition (the Oxford model) but with the primary sources that underlie it. We have traditionally listed editions in bibliographies as primary resources but the digital environment is showing us that they are logically secondary. An edition is, in principle, an argument about those manuscript and printed sources. The reading text in the printed edition embodies the argument, which the apparatus supports.

This will remain so in the digital medium. Cutting the reader off from the original sources and instead providing a distilled record of them in the form of a textual apparatus was unavoidable in the past, but it no longer is. That is why a digital edition needs to rest on a digital archive in which the transmission of the literary work is fully exposed by facsimile images of the sources and checked transcriptions of them, and by the automatic collation of the latter. These resources then become the basis of interpretation for textual, editorial and more broadly interpretative approaches.

The digital edition of the work or of its versions can then be built on top of the archive. Automatic collation of the transcripts is already possible. This facility gives the editor the 
basic data on which to analyse the textual transmission of the work. Argued grounds for the establishment of a reading text can then emerge. But they will not prevent the establishment of another edition linked to the same source documents but edited on different grounds.

With the printed form this multiplying of editions is effectively ruled out. One can count on the fingers of one hand the number of anglophone authors for whom the marketplace can tolerate competing full-scale scholarly editions of their works. Yet we know Shakespeare is the best example - that different editorial approaches to an author's works typically evolve over time. In the digital ecology this process can be expedited. Each new competing edition will take its chances of survival, with its embodied argument either convincing or not convincing the scholarly community. In the long term it will become part of the history of the work.

The provision of annotation by a collaborative community of scholars also becomes possible in the digital environment. Their contributions would be signed, dated, given a digital object identifier (DOI) - in effect, formally published - and permanently preserved. Thus the edition's design would build updating into itself.

For an essentially versional author like Lawrence the crucial matter becomes the avenues of access that the reader can be offered. These need to include by work and version title as well as by first lines in the case of poetry; via date of composition, revision and production; and conceivably via subject (see further below); as well as via accurate character-string searches. (Disturbingly, searches of XML marked-up documents, which constitute a large proportion of those we encounter online today, typically are not reliable.)

Perhaps the most fundamental access point for a versional author will be via a timeline that displays the chronological overlap of the various versions of the different works being written or prepared around the same time, whether manuscript, typescript or proofs of the poem, short story, essay, play or novel. It would be but a short step to incorporate Lawrence's letters into what I would call the D. H. Lawrence Critical Archive: both archive and critical edition at once. The interplay between Lawrence's reading and writing would then become more immediately visible and thus more amenable to interpretation.

The aim would be to better understand the development of versions within a work as well as the continuities of or shifts in subject and approach among versions of multiple contemporaneous works. Such continuities and shifts arise naturally from their more-orless shared biographical environment of living and reading and writing. Obviously, reading texts established on eclectic principles (such as texts of final authorial intention usually aimed at in printed critical editions of modern anglophone authors) would not serve this archival goal well since their reading texts mix up the fundamental chronological testimony of the various documents. (On the other hand they do serve their own editorial goal with a very well established methodology.) 
In practice the exposure of a versional Lawrence would require an onscreen 'workbench' (deliberately ambiguous term) for the reader-user in which transcriptions of any two versions of the same work could be viewed side-by-side with variants high-lighted; or any one version could be encountered next to its facsimile image, with the two synchronously scrolling. 25

Introduction of the vector of time into the critical archive, visualised via a timeline or some other tool, with direct transfer from it to the relevant facsimiles and transcriptions would facilitate inter-versional, inter-work and ultimately biographical commentary since the focus of the commentary would be immediately in front of the reader as never before. Such commentary is far more difficult when one has to rely on the report of variation in a textual apparatus in order to reconstruct the alternative versions. Categories of silent emendation and reporting (as in the Lawrence Works editions), and the habit of other series of only recording variant substantives (rather than substantives and accidentals), make such reconstructions only partially reliable. In addition, a tool allowing the generation of subject terms from this growing body of collaboratively contributed commentary would in due course provide another, index-like mode of access to the versionality that Lawrence's writings display.

A widely held assumption among digital humanities researchers is that all aspects of the development of such projects should be the province of academics working with programmer-designers, with an institutional repository's archival database and server at their disposal. Such in-house projects are, as a result, almost necessarily grant-funded. Yet grants come only with a significant impost: the excessive time that is lost in grantwriting. The alternative - having a Critical Archive formally published and maintained by a university press - would bring some advantages with it. The responsibilities of platform-building, file preservation, permissions, contracts, promotion, royalties, would be lifted from the scholars' shoulders, and the arm's-length imprimatur for the project would also be useful. This arrangement would allow humanities scholars to get on with doing what they do best: interpret.

But would it make commercial sense for the publisher? Obviously there would be risk and some bravery would initially be called for. This is not something upon which I can yet offer a confident opinion except to say that print outputs of a part or parts of the critical archive aimed at and available to be sold to different audiences are readily imaginable. Now they would be understood as, and would be, derivatives, not vice versa, as in the current situation with the Oxford and the forthcoming Cambridge online editions. ${ }^{26}$

25 This is already technically feasible and does not necessarily require complex XML mark-up of the transcription files, such as the Oxford model uses, to achieve it.

26 Much of the thinking about the technical matters broached here has come from my involvement with programmer Desmond Schmidt in the building of a critical archive of an Australian colonial poet, Charles Harpur. At the time of writing, the site (charles-harpur.org) is still in development. Its 'Technical Design' essay should be consulted, as well as Schmidt's articles listed there. For the archival-editorial distinction relied upon here see its 'Archival and Editorial Policy'; Meredith Sherlock was the digital archivist for the 
Eggert . 'Studying works, studying versions' . p. 13

project. For countless conversations over the last twenty years - which have influenced the ideas presented in this Coda about the workings of a critical archive - I am also indebted to Graham Barwell, Phillip Berrie, Anna Gerber, Roger Osborne, Peter Shillingsburg and Chris Tiffin. 